UDC: $930=111(091)$

Даніеле Кастріціо

$\mathrm{Ph}$. D., професор з нумізматики

Університету Мессіни

(Мессіна, Італія)

DOI: https://doi.org/10.31470/2616-6275-2021-5-105-120

Daniele Castrizio

Ph. D., professor of Numismatics in the University of Messina

(Messina, Italy)

ORCID: 0000-0001-6435-4922

dcastrizio@unime.it

\title{
THE ANTIKYTHERA WRECK: A NUMISMATIC APPROACH
}

\section{АВАРІЯ НА АНТИКІТЕРІ: НУМІЗМАТИЧНИЙ ПІДХІД}

\begin{abstract}
.
The paper examines the coins found inside the Antikythera wreck. The wreck of Antikythera was discovered by chance by some sponge fishermen in October 1900, in the northern part of the island of Antikythera. The archaeological excavation of the wreck has allowed the recovery of many finds in marble and bronze, with acquisitions of human skeletons related to the crew of the sunken ship, in addition to the famous "Antikythera mechanism".

Various proposals have been made for the chronology of the shipwreck, as well as the port of departure of the ship, which have been based on literary sources or on the chronology of ceramic finds.

As far as coins are concerned, it should be remembered that thirty-six silver coins and some forty bronze coins were recovered in 1976, all corroded and covered by encrustations. The separate study of the two classes of materials, those Aegean and those Sicilian allows to deepen the history of the ship shipwrecked to Antikythera.

The treasury of silver coinage is composed of thirty-six silver cistophoric tetradrachms, 32 of which are attributable to the mint of Pergamon and 4 to that of Ephesus. From the chronological point of view, the coins minted in Pergamon have been attributed by scholars to the years from 104/98 B.C. to 76/67 B.C., the date that marks the end of the coinage until 59 B.C. The coins of Ephesus are easier to date because they report the year of issue, even if, in the specimens found, the only legible refers to the year 53, corresponding to our 77/76 B.C., if it is assumed as the beginning of the era of Ephesus its elevation to the capital of the province of Asia in 129 B.C., or 82/81 B.C., if we consider 134/133 B.C., the year of the creation of the Provincia Asiana.

As for the three legible bronzes, we note that there are a specimen of Cnidus and two of Ephesus. The coin of the city of Caria was dated by scholars in the second half of the third century B.C. The two bronzes of Ephesus are dated almost
\end{abstract}


unanimously around the middle of the first century B.C., although this fundamental data was never considered for the dating of the shipwreck.

The remaining three legible bronzes from Asian mints, two from the Katane mint and one from the Panormos mint, belong to a completely different geographical context, such as Sicily, with its own circulation of coins. The two coins of Katane show a typology with a right-facing head of Dionysus with ivy crown, while on the reverse we find the figures of the Pii Fratres of Katane, Amphinomos and Anapias, with their parents on their shoulders.

The specimen of Panormos has on the front the graduated head of Zeus turned to the left, and on the verse the standing figure of a warrior with whole panoply, in the act of offering a libation, with on the left the monogram of the name of the mint.

As regards the series of Katane, usually dated to the second century B.C., it should be noted, as, moreover, had already noticed Michael Crawford, that there is an extraordinary similarity between the reverse of these bronzes and that of the issuance of silver denarii in the name of Sextus Pompey, that have on the front the head of the general, facing right, and towards the two brothers from Katane on the sides of a figure of Neptune with an aplustre in his right hand, and the foot resting on the bow of the ship, dated around 40 B.C., during the course of the Bellum siculum. We wonder how it is possible to justify the presence in a wreck of the half of the first century B.C. of two specimens of a very rare series of one hundred and fifty years before, but well known to the engravers of the coins of Sextus Pompey. The only possible answer is that Katane coins have been minted more recently than scholars have established.

For the coin series of Panormos, then, it must be kept in mind that there are three different variants of the same type of reverse, for which it is not possible to indicate a relative chronology. In one coin issue, the legend of the ethnic is written in Greek characters all around the warrior; in another coin we have a monogram that can be easily dissolved as an abbreviation of the name of the city of Panormos; in the third, in addition to the same monogram, we find the legend CATO, written in Latin characters. In our opinion, this legend must necessarily refer to the presence in Sicily of Marcus Porcius Cato of Utica, with the charge of propraetor in the year 49 B.C. Drawing the necessary consequences from the in-depth analysis, the data of the Sicilian coins seem to attest to their production towards the middle of the first century B.C., in line with what is obtained from the ceramic material found inside the shipwrecked ship, and from the dating of the coins of Ephesus.

The study of numismatic materials and a proposal of more precise dating allows to offer a new chronological data for the sinking of the ship. The presence of rare bronze coins of Sicilian mints suggests that the ship came from a port on the island, most likely from that of Katane.

Keywords: Numismatics; Iconography; Antikythera wreck; Greek Archaeology; Roman History; Greek History. 


\section{Анотація.}

У роботі досліджуються монети, знайдені на залишках аварії на Антикітері. Затонулий корабель випадково виявили рибалки у жовтні 1900 року в північній частині острова Антикітера. Археологічні розкопки затонулого судна дозволили відновити багато знахідок з мармуру та бронзи, а також відомі «антикітерські механізми», де були виявлені людські скелети, пов 'язані з екіпажем затонулого корабля.

Мали місще різні пропозищіі щуодо хронології аварії, а також порту відправлення корабля, які базувалися на літературних джерелах або на хронологї виявленої кераміки.

Щодо монет, то слід пригадати, щзо у 1976 р. було виявлено 36 срібних та близько сорока бронзових монет, усі вони кородовані та покриті стійким нальотом. Окреме вивчення двох класів матеріалів - егейського та сицилійського - дозволяє поглибити історію аварії корабля на Антикітері.

Скарб срібних монет складається з тридияти шести изистофорних тетрадрахм, 32 з яких відносяться до монетного двору Пергамону, а 4 - до Ефесу. Із хронологічної точки зору, монети, викарбувані в Пергамоні, були віднесені вченими до періоду з 104-98 років до н.е. до 76-67 років до н. е., дата закінчення карбування монети - до 59 р. до н.е. Ефеські монети легше датувати, оскільки на них зазначений рік випуску, навіть якщо у знайдених зразках єдиний розбірливо зафіксований 53 рік, щзо відповідає нашому 77-76 рр. до н.е.. Якщзо вважати цей рік початком епохи Ефесу, ї̈ піднесення до столииі провінщії Азія у 129 р. до н. е., або 82-81 р. до н. е., якщо розглядати 134-133 р. до н. е., тобто рік створення провіниії Азіана.

Стосовно трьох ідентифікованих бронзових монет зазначимо, щуо вони представляють зразки карбування Кніду (одна монета) та Ефесу (дві монети). Монета міста Карія була датована вченими другою половиною третього століття до н.е. Дві бронзові монети Ефесу датуються приблизно серединою першого століття до нашої ери, хоча ијі фундаментальні дані ніколи не враховувалися для датування корабельної аварії.

Серед інших трьох ідентифікованих бронзових монет з азіатських монетних дворів дві монети з монетного двору Катане та одна з монетного двору Панормоса належать до зовсім іншого географічного контексту, такого як Сищилія із власним грошовим обігом. Дві монети Катане за типологією $з$ правою головою Діоніса з короною, тоді як на звороті ми знаходимо фігури Пія Фратреса з Катане, Амфіномоса та Анапія, з батьками на плечах.

Монета Панормоса має на передній частині градуйовану голову Зевса, повернену ліворуч, а на реверсі - стоячу постать воїна у повному військовому обладунку, зліва монограма монетного двору.

Що стосується серії монет Катане, яка, зазвичай, датується другим століттям до нашої ери, то історію про неї слід доповнити спостереженням 
Майкла Кроуфорда про те, щуо існує надзвичайна подібність між реверсом иуих бронзових монет та випуском срібних динаріїв на честь Секста Помпея, щзо має на аверсі обернену праворуч голову генерала, а в бік - двох братів з Катане по сторонах від фігури Нептуна з аплюстром у правій руці, а ногою він спирається на ніс корабля, датований приблизно 40 роком до намої ери, періодом Belluт siculum. Вражає те, щзо на місці аварії присутні два екземпляри дуже рідкісної серії монет половини першого століття до н.е. за сто п'ятдесят років до ичього, але добре відомих монет як монет граверам Секста Помпея. Сдина можлива відповідь: монети Катане були викарбувані раніше, ніж установили вчені.

Тому для серії монет Рапоттоs слід мати на увазі, щуо існують три різні варіанти одного типу реверсу, для яких неможливо вказати відносну хронологію. В одному випуску монет легенда етнічної мови написана грецькими ієрогліфами навколо воїна; в іншій монеті ми маємо монограму, яку можна легко прочитати як абревіатуру назви міста Панормос; у третьому, крім тієї ж монограми, ми знаходимо легенду САТО, написану латинськими буквами. На нашу думку, ияя легенда неодмінно має посилатися на присутність у Сицилії Марка Пориія Катона з Утіки, звинувачений пропретором у 49 рочі до н.е. Детальний аналіз даних сищилійських монет свідчить про їх виробництво до середини першого століття до нашої ери, щуо підтверджується керамічним матеріалом, знайденим всередині корабля, щзо зазнав аварії, а також датуванням монет Ефесу.

Вивчення нумізматичних матеріалів та пропозиція більш точного датування дозволяють запропонувати нові хронологічні дані про затоплення корабля. Наявність рідкісних бронзових монет сищилійських монетних дворів говорить про те, щцо корабель прибув з порту на острів, швидше за все, з порту Катане.

Ключові слова: нумізматика; іконопис; руїни Антикітера; археологія Греиї; історія Риму; історія Греції.

\section{Sommario}

Lo studio esamina le monete trovate all'interno del relitto di Anticitera, che fu scoperto per caso da alcuni pescatori di spugne nell'ottobre 1900, nella parte settentrionale dell'isola di Anticitera. Lo scavo archeologico del relitto ha permesso il recupero di molti reperti in marmo e bronzo, con acquisizioni di scheletri umani relativi all'equipaggio della nave affondata, oltre al famoso "meccanismo di Anticitera".

Sono state avanzate diverse proposte per la cronologia del naufragio, nonché per il porto di partenza della nave, che si basano su fonti letterarie o sulla cronologia dei reperti ceramici. 
Per quanto riguarda le monete, va ricordato che trentasei monete d'argento e una quarantina di monete in bronzo sono state recuperate nel 1976, tutte corrose e ricoperte da incrostazioni. Lo studio separato delle due classi di materiali, quelle egee e quelle siciliane, permette oggi di approfondire la storia della nave naufragata ad Anticitera.

Il tesoro di monete d'argento è composto da trentasei tetradrammi cistoforici, trentadue dei quali sono attribuibili alla zecca di Pergamo e quattro a quella di Efeso. Dal punto di vista cronologico, le monete coniate a Pergamo sono state attribuite dagli studiosi agli anni dal 104/98 a.C. al 76/67 a.C., data che segna la fine della monetazione fino al 59 a.C. Le monete di Efeso sono più facili da datare, perché riportano l'anno di emissione, anche se, negli esemplari rinvenuti, l'unico leggibile si riferisce all'anno 53 dell'Era locale, corrispondente al nostro 77/76 a.C., se si assume come inizio dell'era di Efeso la sua elevazione a capitale della provincia di Asia nel 129 a.C., o al nostro 82/81 a.C., se si considera il 134/133 a.C., anno della creazione della Provincia Asiana.

Per quanto riguarda i tre bronzi leggibili di zecca anatolica, notiamo che ci sono un esemplare di Cnido e due di Efeso. La moneta della città della Caria è stata datata dagli studiosi nella seconda metà del III secolo a.C. I due bronzi di Efeso sono datati quasi all'unanimità intorno alla metà del I secolo a.C., anche se questo dato fondamentale non è mai stato preso in considerazione per la datazione del naufragio.

I restanti tre bronzi leggibili, due della zecca di Katane e uno della zecca di Panormos, appartengono a un contesto geografico completamente diverso, come la Sicilia, con una propria circolazione di monete. I due esemplari di Katane mostrano una tipologia con la testa rivolta a destra di Dioniso con corona di edera, mentre sul rovescio troviamo le figure dei Pii Fratres di Katane, Amphinomos e Anapias, con i genitori sulle spalle.

L'esemplare di Panormos ha sul recto la testa laureata di Zeus volta a sinistra, e sul verso la figura in piedi di un guerriero con panoplia intera, nell'atto di offrire una libagione, con a sinistra il monogramma del nome della zecca.

Per quanto riguarda la serie di Katane, solitamente datata al II secolo a.C., dovrebbe essere notato, come del resto aveva già segnalato Michael Crawford, che vi è una straordinaria somiglianza tra il rovescio di questi bronzi e quello dell'emissione di denari d'argento a nome di Sesto Pompeo, che hanno sul diritto la testa del generale, volta a destra, e sul rovescio i due fratelli da Katane ai lati di una figura di Nettuno con un aplustre nella mano destra, e il piede che si posa sulla prua di una nave da guerra, moneta che è genericamente datata intorno al 40 a.C., durante il corso del Bellum siculum. Ci domandiamo come sia possibile giustificare la presenza in un relitto della metà del primo secolo a.C. di due esemplari di una rarissima serie di centocinquanta anni prima, ma ben nota agli incisori delle monete di Sesto Pompeo. L'unica risposta possibile è che le monete di Katane sono state coniate più recentemente di quanto gli studiosi abbiano stabilito. 
Per la serie di monete di Panormos, poi, va tenuto presente che esistono tre diverse varianti dello stesso tipo di rovescio, per le quali non è possibile indicare una cronologia relativa. In una moneta, la leggenda dell'etnico è scritta in caratteri greci tutt'intorno al guerriero; in un'altra moneta abbiamo un monogramma che può essere facilmente sciolto come abbreviazione del nome della città di Panormos; nel terzo, oltre allo stesso monogramma, troviamo la leggenda CATO, scritta in caratteri latini. A nostro avviso, questa leggenda deve necessariamente riferirsi alla presenza in Sicilia di Marco Porcio Catone di Utica, con l'incarico di propretore nell'anno 49 a.C.

Traendo le conseguenze necessarie dall'analisi, i dati delle monete siciliane sembrano attestare la loro produzione verso la metà del I secolo a.C., in linea con quanto si ricava dal materiale ceramico rinvenuto all' interno della nave naufragata, e dalla datazione delle monete di Efeso.

Lo studio dei materiali numismatici e una proposta di datazione più precisa permette di offrire nuovi dati cronologici per l'affondamento della nave. La presenza di rare monete in bronzo di zecche siciliane suggerisce che la nave provenisse da un porto dell'isola, probabilmente da quello di Katane.

The wreck of Antikythera was discovered by chance by some sponge fishermen in October 1900, in the northern part of the island of Antikythera, inside the Gulf of Kaminakia, near the islets called Thermones, north of Cape Kolimba, at a depth of about 50 meters and a distance from the coast of 25 meters ${ }^{1}$. The first searches, with permission granted by the Ministry of Culture and the Greek Navy, were conducted by the same discoverers, who managed to recover many fragments of bronze and marble statues and other finds ${ }^{2}$, including the "Antikythera mechanism", now in the National Archaeological Museum of Athens ${ }^{3}$. This research was suspended in 1901, due to the death of several divers due to embolism from decompression.

In 1953 and 1976, the explorer Jacques Cousteau devoted himself to some research on the site of the shipwreck, recovering some artifacts, including coins and a silver coin hoard, which we will discuss below.

Real systematic research resumed between 2012 and 2013, when marine archaeologist Brendan P. Foley was authorized by the Greek government to investigate the seabed of Antikythera. Since 2014, the new campaigns, as part of an international expedition equipped with modern equipment, are allowing to expand the number of finds in marble and bronze ${ }^{4}$, with acquisitions of human skeletons related to the crew of the sunken ship ${ }^{5}$, as well as new boat elements. Among the new findings, a type of weapon known from sources, but never found until now, deserves a mention. It is the so-called dolphin, a mass of lead with an iron point, used to be dropped on the enemy

\footnotetext{
${ }^{1}$ Stais 1905; Svoronos 1903; Bol 1972; Kaltsas et al. 2012.

${ }^{2}$ Vlachogianni 2012.

${ }^{3}$ Edmunds, Morgan 2000; Freeth et al. 2006; Freeth, Jones, Steele, Bitsakis 2008; Wright 2004.

${ }^{4}$ Palaiokrassa 2012, 116-131.

${ }^{5}$ Nafplioti 2012, 57-60.
} 
ship from the top of the flagpole, in order to hit and cross the bridge and the enemy hull because of its own weight and the tip, to produce a leak that could cause it to sink.

The new research has also made it possible to understand the actual size of the sunken ship, which, with its about fifty meters in length, is one of the largest known wrecks in the ancient world. The topic of our study does not concern the archaeological finds discovered in the wreck and the "Antikythera mechanism" but intends to deepen the investigations on the coins found inside the ship, trying to shed new light on the port of departure of the ship.

\section{The chronology of the shipwreck}

Various proposals have been made for the chronology of the shipwreck, as well as the port of departure of the ship ${ }^{1}$. A theory is based solely on a passage by Lucian of Samosata $^{2}$, in which it is attested that the original of a painting, of which a perfect copy was in Athens at that time, had been sent in Italy by Lucius Cornelius Sulla Felix with other sixty-eight works of art, on a cargo ship (a holkàs, as quoted from the source), which had subsequently sunk near Cape Malea in the Peloponnese ${ }^{3}$. Objectively, it is difficult to prove that the ship of Silla, sunk in 86 B.C., is the same found on the seabed near Antikythera, also because Cape Malea is very far from the island located in the stretch of sea between Crete and the Peloponnese.

Another method of providing a chronology was to use the dates of the amphorae found in the wreck. Most of the precious ceramics found belong to the socalled eastern sigillata A (ESA), a variant of Hellenistic ceramics, very common between II and I century B.C. ${ }^{4}$, but there are also examples of Hellenistic grey ceramics $^{5}$. It is, in all probability, also because of the signs of the use of such crockery, of pottery belonging to the crew of the ship, even if they are present expensive ceramics, that have made to think, in our opinion wrongly, to material destined to the commerce.

In the ship have been found also many lagynoi, amphorae for individual consumption of wine, whose diffusion is attested in the eastern Mediterranean during the Hellenistic period ${ }^{6}$. Because of their great number, it was thought that they too were part of the load more for the contained wine than for the container ${ }^{7}$.

As for the transport amphorae, it should be noted that, among the twenty-one artifacts found, there are specimens produced in Rhodes, Kos and Ephesus, as well as ceramics of the type Lamboglia $2^{8}$. Because of the indeterminacy of the chronology of these ceramic materials, it is well understood that the only fact that seems to be

\footnotetext{
${ }^{1}$ Bouyia 2012, 287-292.

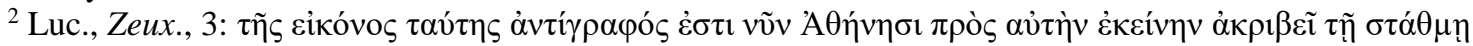

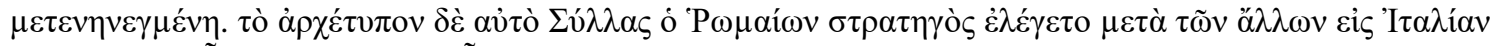

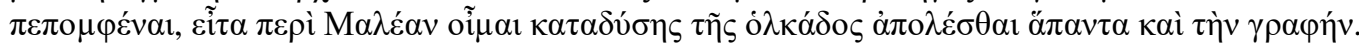

${ }^{3}$ Coarelli 1983, 45-53.

${ }^{4}$ Lund 2005, 233-252.

${ }^{5}$ Slane 1997, 247-416; Privitera 2009, 425-437; Kavvadias 2012, 169-181.

${ }^{6}$ Vivliodetis 2012, 152-163.

${ }^{7}$ Cook 1997, 196-197.

${ }^{8}$ Kourkoumelis 2012, 208-215.
} 
deduced from the material found, is that the shipwreck occurred in the first century B.C. Moreover, given the not very high numbers of pottery found, especially compared to the mass of statues and other objects of great value present in the wreck, it may be necessary to consider the possibility that the ship did not carry out commercial activities, and that, therefore, this part of the cargo can be considered to belong to the galley, to the provisions for the crew of the ship, possibly acquired along the route undertaken ${ }^{1}$.

To conclude the argument, it is also necessary to give an account of the analysis of carbon-14 dating of the elm planking of the vessel, conducted in 1964, which indicated a date ranging between the middle of the third and the first quarter of the second century B.C. As you can guess, apart from the lack of precision typical of the method used, we must also consider the long use of ships in ancient times, especially those of value. In any case, the dating given by the analysis refers to the moment of the cutting of the tree, from which subsequently the wood would have been obtained for the construction of the ship.

\section{The coins in the shipwreck}

As often happens, the safest contribution to the archaeological dating of sites and wrecks is provided by the coins found. The necessary condition is, however, that they be studied by a numismatist, which can provide not only the terminus post quem of the monetary issue, determined, of course, by the date of minting of the series under consideration, but also the terminus ante quem, provided by the knowledge of the circulation of those specimens, that allows to know the historical moment in which they have been demonetized. In the present case, it must first be stated that thirty-six silver coins and some forty bronze coins were recovered in 1976, all corroded and covered by encrustations ${ }^{2}$. The cleaning and restoration of these materials took place at the National Archaeological Museum of Athens, where they are currently kept.

The study of these coins should be subdivided, in our opinion, in two different parts: one that concerns the specimens of microasian mint, both in silver and in bronze, and the other concerning the Sicilian bronzes, falling within two different areas of circulation, not comparable with each other. The separate study of the two classes of materials, those Aegean and those Sicilian, as we will see, allows to deepen the history of the ship shipwrecked to Antikythera. We insist on this aspect: the coins of Sicily that were found in Antikythera are very rare, and have had an extremely limited circulation range, excluding one significant exception, which we will discuss below. Given this premise, we must draw the scientific conclusion that it makes no sense to analyse together Sicilian issues and Aegean coins: the bronzes of Sicily have never circulated regularly in Asia Minor, and are almost impossible to find even beyond the Strait of Scylla, remaining closed in the island.

\footnotetext{
${ }^{1}$ Gadolou 2012, 50-56.

2 Tselekas 2012, 216-226.
} 
In line with this assumption, we are primarily concerned with the micro-Asian currencies, which have been studied with great accuracy by our Greek colleagues: a hoard of Cistophoric Coinage and three bronze coins. The treasury is composed of thirty-six silver cistophoric tetradrachms, 32 of which are attributable to the mint of Pergamon and 4 to that of Ephesus ${ }^{1}$. The typology is typical of the cistophorus $^{2}$ : on the front, the Cista Mystica from which emerge some snakes, with around a garland of ivy with fruit; at the back, two coiled snakes around a gorytos, an eastern quiver for bow and arrows, with around monograms and abbreviations of names of magistrates. Pergamon and Ephesus emissions differ, typologically, by the symbol placed on the right. Among the coins found inside the wreck, in those of Pergamon we see a sacred object variously interpreted by numismatics, on which a serpent is wrapped, which, in our opinion, should represent the sceptre of the king; on the specimens of Ephesus, instead, you recognize a torch.

From the chronological point of view, the coins minted in Pergamon have been attributed by scholars to the years from 104/98 B.C. to 76/67 B.C., the date that marks the end of the coinage until 59 B.C. ${ }^{3}$. The coins of Ephesus are easier to date because they report the year of issue, even if, in the specimens found, the only legible refers to the year 53, corresponding to our 77/76 B.C., if it is assumed as the beginning of the era of Ephesus its elevation to the capital of the province of Asia in 129 B.C., or 82/81 B.C., if we consider 134/133 B.C., the year of the creation of the Provincia Asiana ${ }^{4}$ As always happens in every hoard, fruit of long-term accumulation and hoarding, the presence of specimens coined thirty years before the most recent ones is, from the numismatic point of view, to be considered habitual.

As for the three legible bronzes, we note that there are a specimen of Cnidus and two of Ephesus. The coin of the city of Caria was dated by scholars in the second half of the third century B.C. and has a typology with on the obverse a head of Aphrodite turned to the right, while on the reverse you recognize a ship bow facing right, with legend and name of illegible magistrate ${ }^{5}$. Knowing the monetary circulation of Asia Minor, it is not surprising the discovery of a coin minted by more than a century and a half, in a context of accumulation of specimens that always remained in use, practically until their consumption.

The two bronzes of Ephesus have on the front the bust of Artemis turned to right, with on the shoulder bow and quiver; to the verse we see the forepart of a stag kneeling, with torch to the left, legend and name of magistrate ${ }^{6}$. On the two coins from the wreck, you can read the names of two magistrates: Menophilos e Demetrios. The

\footnotetext{
${ }^{1}$ Oikonomidou 2001, 541-544; Tselekas 2012, 216-226.

${ }^{2}$ Kleiner-Noe 1977.

${ }^{3}$ Kleiner 1978, 77-105.

${ }^{4}$ Kleiner 1972.

${ }^{5}$ SNG Copenhagen, n. 308.

${ }^{6}$ SNG Copenhagen, n. 340.
} 
series is dated almost unanimously around the middle of the first century B.C., although this fundamental data was never considered for the dating of the shipwreck.

The remaining three legible bronzes, two from the Katane mint and one from the Panormos mint, belong to a completely different geographical context, such as Sicily, with its own circulation of coins. The two coins of Katane show a typology with a right-facing head of Dionysus with ivy crown, and legend $\Lambda \mathrm{A} \Sigma \mathrm{IO}^{1}$, while on the reverse we find the figures of the Pii Fratres of Katane, Amphinomos and Anapias, with their parents on their shoulders, and above the legend KATANAI $\Omega N^{2}$.

The specimen of Panormos has on the front the graduated head of Zeus turned to the left, and on the verse the standing figure of a warrior with whole panoply, in the act of offering a libation, with on the left the monogram of the name of the mint ${ }^{3}$.

Concerning the studies on the two bronze coin series, should be noted that the chronologies proposed by the existing bibliography are vague and questionable, not relying on any evidence, but simply on the sensitivity of the numismatics who have studied them, and sometimes only on "iconographic fashions", also important, but often fallacious ${ }^{4}$.

More specifically, as regards the series of Katane (fig. 1), usually dated to the second century B.C., it should be noted, as, moreover, had already noticed Michael Crawford $^{5}$, that there is an extraordinary similarity between the reverse of these bronzes and that of the issuance of silver denarii in the name of Sextus Pompey, that have on the front the head of the general, facing right, and towards the two brothers from Catania on the sides of a figure of Neptune with an aplustre in his right hand, and the foot resting on the bow of the ship, dated around 40 B.C., during the course of the Bellum siculum ${ }^{6}$ (fig 2). The type of Neptune, shown as the winner of a naval battle thanks to the presence of the aplustre torn by an enemy ship, used as a trophy, recalls the statue of Poseidon Porthmios, that was in Porticello di Villa San Giovanni, in whose waters a naval battle took place, won by the son of Pompey Magnus ${ }^{7}$. We wonder how it is possible to justify the presence in a wreck of the half of the first century B.C. of two specimens of a very rare series of one hundred and fifty years before, but well known to the engravers of the coins of Sextus Pompey. The only possible answer is that Katane coins have been minted more recently than scholars have established.

For the coin series of Panormos, then, it must be kept in mind that there are three different variants of the same type of reverse, for which it is not possible, at the

\footnotetext{
${ }^{1}$ Kroll 1924, 887; Pailler 1988

${ }^{2}$ HGC 2, 630; CNS III 13.

${ }^{3}$ CNS I, 117.

${ }^{4}$ Holm 1898; Mirone 1916, 223-234; Gabrici 1927; Consolo Langher 1964; Arnold-Biucchi 1981, 717-718; Calciati 1983-1987; Caccamo Caltabiano 1988, 353-379; Manganaro 1996, 303-329; Campana 1999, 17-19; Casabona 1999; Caccamo Caltabiano 2004, 49-75; Carroccio 2004.

${ }^{5}$ Crawford 1974, 520.

${ }^{6}$ Crawford 1974, n. 511/3a.

${ }^{7}$ Castrizio 2018, 71-82.
} 
moment, to indicate a relative chronology. In one coin issue, the legend of the ethnic is written in Greek characters all around the warrior ${ }^{1}$ (fig. 3); in another coin we have a monogram that can be easily dissolved as an abbreviation of the name of the city of Panormos $^{2}$ (fig. 4); in the third, in addition to the same monogram, we find the legend CATO, written in Latin characters ${ }^{3}$ (fig. 5). In our opinion, this legend must necessarily refer to the presence in Sicily of Marcus Porcius Cato of Utica, with the charge of propraetor in the year 49 B.C. Caesar testifies that, at the beginning of the Bellum Civile, Cato, to whom Sicily had been assigned, had begun to repair the ships of the Sicilian war fleet, as well as to request new vessels from the island communities, but then he leaved the island for the arrival of an army sent by Caesar ${ }^{4}$. The presence of a precise terminus ad quem for the coinage of the series of Panormos with CATO legend, of course, provides a date for the series that presents the only monogram citizen, which is found in the wreck of Antikythera, with all known specimens falling within the same weight range.

Drawing the necessary consequences from the in-depth analysis, the data of the Sicilian coins seem to attest to their production towards the middle of the first century B.C., in line with what is obtained from the ceramic material found inside the shipwrecked ship, and from the dating of the coins of Ephesus.

If read under the lens of the numismatic study, the data from the coins of the shipwreck seem to attest to two different areas of circulation, to which the various coins refer. It should be noted, in fact, that there was not, in that historical period, a Mediterranean circulation of bronze coins. From the data in our possession, except for very limited exceptions, the range of circulation of the bronze nominal is always very limited. Except for some very rare examples, among which the discovery at Delos of a single coin of the series of Katane with Dionysus and the Pii fratres ${ }^{5}$, the bronze coins of Asia Minor are not found in Sicily, and Sicilian coins are not found in Anatolia ${ }^{6}$.

The first coherent area of circulation is Anatolia. The treasure of Cistophoric coins and bronze specimens must necessarily be related to the destination or one of the ports touched by the boat, where were loaded all the artistic treasures destined to Rome. The presence of four silver coins of the mint of Ephesus, not so common as those of Pergamon, as well as two bronzes of the same mint, seems to indicate in the capital of the Province of Asia an important stage in the maritime route of the ship.

We must note a second area of circulation, separated from the first, which is focused on the ports of Panormos and Katane. In order to understand the importance of the Sicilian bronze finds, it is necessary to say again how these coins are very rare

\footnotetext{
${ }^{1}$ CNS I, n. 8; HGC 2, n. 1081. NUMISMATIK NAUMANN (FORMERLY GITBUD \& NAUMANN), AUCTION 53, LOT 32.

${ }^{2}$ CNS I, n. 117; SNG ANS, nn. 586-8. BERTOLAMI FINE ARTS, E-AUCTION 83, LOT 420.

${ }^{3}$ CNS I, n. 120; HGC 2, n. 1071.BERTOLAMI FINE ARTS, E-AUCTION 60, LOT 126.

${ }^{4}$ Caes., De bello civili, I, 30: Cato in Sicilia naves longas veteres reficiebat, novas civitatibus imperabat. (...)

Haec in contione questus ex provincia fugit.

${ }^{5}$ Hackens 1983, 107-111; Bruneau 1968, 633-709.

${ }^{6}$ Hackens 1968, 119-129.
} 
outside Sicily, also in the near Calabria. It is a local numerary, intended for circulation in Sicily, whose presence on board the boat cannot be explained in any other way, except postulating the provenance of the ship from Sicily.

At the end of the examination, it seems to us that it is necessary to try to look at the wreck, considering the acquired data not contestable. The first consideration concerns the provenance of the large transport vessel, whose sailors possessed rare Sicilian emissions, which would seem to indicate a Sicilian vessel used for the transport, perhaps public, of war preys from the East, probably in the age of Caesar. It should not be forgotten, in this regard, that the inscriptions present on the "Antikythera mechanism" found on the wreck are written with letters characteristic of the alphabet of Corinth, typical of Syracuse.

The "mechanism" opens a whole series of doubts on the material transported from the ship, that it is considered like part of a cargo of goods to sell. In our opinion, as we have pointed out above, the low number of amphorae present seems to refer more to a galley, than to merchandise to sell or exchange. The variety of types can be explained by the well-known practice of buying fresh food and drinks in the various ports where you landed. In this perspective, even the various lagoons found should have been purchased by the crew during the journey from Sicily to Ephesus. Regarding the route followed from the ship, the presence of a bronze specimen of Katane in the monetary discoveries in the archaeological excavations of Delos shows, in our opinion, the importance of the island sacred to Apollo and Artemis. Delos is a port used in the routes between Italy and the East. It is also useful to repeat how Kythera and Antikythera were in ancient times two fundamental harbours along the same route, since they were to be the only landmarks in the stretch of sea between Crete and the Peloponnese, one of the most dangerous of the entire itinerary.

Only further studies and research will clarify which objects were the property of the owner or captain of the sunken ship in Antikythera, and which, instead, represented the cargo that had embarked in the East, in respect of which, I believe it is still necessary to investigate whether these are intact works of art to be brought to Rome or whether, together with them, parts of ruined statues had been loaded, to be used as metal to be melted. Then there remains the most intriguing question to ask researchers: what was the function of the "mechanism"? Is it a system for determining the day and year, starting from the position of the main visible planets, or was it built for an unknown purpose?

\section{References}

Arnold-Biucchi 1981; Arnold-Biucchi C., "Amphinomos et Anapias", LIMC 1.1, Zürich/München, 717-718.

Bol 1972: P.C. Bol, Die Skulpturen des Schiffsfundes von Antikythera, Berlin.

Bouyia 2012; Bouyia P., "Maritime commerce and luxury in the age of Cicero", in Kaltsas et al., 287-292. 
Bromley 1990: Bromley A.G., "Observations of the Antikythera Mechanism", Antiquarian Horology 18, 641-652.

Bruneau 1968: Bruneau Ph., "Contribution à l'histoire urbaine de Délos à l'époque hellénistique et à l'époque impériale", B.C.H, 92, 633-709.

Caccamo Caltabiano 1988; Caccamo Caltabiano M., "La cronologia del municipium di Henna: discordanza tra il dato numismatico e quello storiografico", in Hestiasis. Studi di tarda antichità offerti a Salvatore Calderone, V, Messina, 353-379.

Caccamo Caltabiano 2004: Caccamo Caltabiano M., "Nuove prospettive dell'indagine sulla monetazione siciliana di 'età romana'", in M. Caccamo Caltabiano, L. Campagna, A. Pinzone (a cura di), Nuove prospettive della ricerca sulla Sicilia del II sec. a.C. Archeologia, numismatica, storia, Messina, 49-75.

Calciati 1983-1987: Calciati R., Corpus Nummorum Siculorum. La monetazione di bronzo, I-III, Milano.

Campana 1999: Campana A, "Il chalkous a Katane", Panorama Numismatico, 129, 17-19.

Carroccio 2004; Carroccio B., Dal basileus Agatocle a Roma. Le monetazioni siciliane d'età ellenistica, Messina.

Casabona 1999: Casabona M., "Le monete di Catana ellenistica tra Roma e le influenze orientali", RIN, 100, 13-46.

Castrizio 2018: Castrizio D., Note di iconografia magnogreca, Messina.

Coarelli 1983: Coarelli F., "Il commercio delle opere d'arte in età tardorepubblicana", DialA, 3, 45-53.

Consolo Langher 1964: Consolo Langher S.N., Contributo alla storia della antica moneta bronzea in Sicilia, Milano.

Cook 1997: Cook R. M., Greek Painted Pottery, London - New York, 196-197.

Crawford 1974: Crawford M.H., Roman Republican Coinage, Cambridge 1974.

Edmunds, Morgan 2000: Edmunds M., Morgan P, "The Antikythera Mechanism: still a mystery of Greek astronomy?" Astronomy and Geophysics 41, 6.10-6.17.

Freeth et al. 2006: Freeth T., "Decoding the ancient Greek astronomical calculator known as the Antikythera Mechanism." Nature 444, 587-591.

Freeth, Jones, Steele, Bitsakis 2008: Freeth T., Jones A., Steele J. M., and Bitsakis Y., "Calendars with Olympiad display and eclipse prediction on the Antikythera Mechanism." Nature 454, 614-617.

Gabrici 1927; Gabrici E., La monetazione del bronzo nella Sicilia antica, Palermo.

Gadolou 2012; Gadolou A., "Life on board", in KALTSAS et al., 50-56.

Hackens 1968: Hackens T., "Notes et documents. Monnaies d'Italie et de Sicile circulant en Grèce", $R B N, 114,119-129$.

Hackens 1983: Hackens T., "Les monnaies", in Ph. Bruneau, J. Ducat, Guide de Délos, Paris, 107-111.

Holm 1898: Holm A., Storia della moneta siciliana, Torino. 
Kaltsas et al. 2012: Kaltas N., Vlachogianni E., Bouyia P. (eds.), The Antikythera Shipwreck, the ship, the treasures, the mechanism (National Archaeological Museum, April 2012 - April 2013), Athens.

Kavvadias 2012: Kavvadias G., "The red-slipped tableware”, in Kaltsas et al., 169181.

Kleiner 1972: Kleiner F.S., “The Dated Cistophori of Ephesus”, AnsMusNotes 18, 1732.

Kleiner 1978: Kleiner F.S., "Hoard Evidence and the Late Cistophori of Pergamum”, ANSMN, 23, 77-105.

Kleiner-Noe 1977: Kleiner F.S., Noe S.P., The Early Cistophoric Coinage, New York. Kroll 1924: Kroll H., "Lasios", in RE XII, 1, 887.

Kourkoumelis 2012: Kourkoumelis D., "Transport amphorae”, in Kaltsas et al., 208215.

Lund 2005: Lund J., “An Economy of Consumption: The Eastern Sigillata. A Industry in the Late Hellenistic Period", in Archibald Z.H., Davies J.K., Gabrielsen V. (eds.) Making, Moving and Managing. The New World of Ancient Economies, 323-31 B.C., Oxford, 233-252.

Manganaro 1996: Manganaro G., "La monetazione di Katane dal V al I sec. a.C.", in

B. Gentili (a cura di), Catania antica, Pisa-Roma, 303-329.

Mirone 1916: Mirone S., "Le monete coniate in Catania in memoria dei Pii fratres", RIN, 17, 223-234.

Nafplioti 2012: Nafplioti A., "The human skeletal remains", in Kaltsas et al., 57-60.

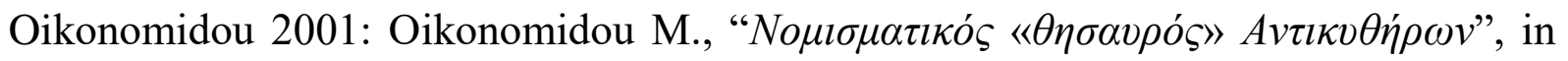

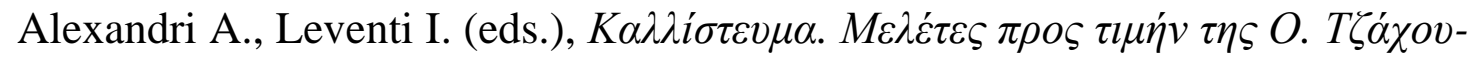
$A \lambda \varepsilon \xi \alpha v \delta \rho \eta \dot{~}$, Athens, 541-544.

Pailler 1988: Pailler J.-M., Bacchanalia. La repression de 186 av. J.-C. à Rome et en Italie, Roma.

Palaiokrassa 2012: Palaiokrassa N., "Small metal objects and utensils", in Kaltsas et al., 116-131.

Perassi 1994: Perassi C., "I Pii Fratres e il Pius Aeneas. Problemi circa l'iconografia di monete della Sicilia e dell'età repubblicana romana", Aevum, 68, 59-87.

Privitera 2009: Privitera S., "Due rilievi greci da Catania e il commercio di opere d'arte nella Sicilia tardo-repubblicana", ASAtene, 87, 425-437.

Privitera 2016: Privitera S., "Nelle tasche dei marinai. Le monete siciliane da Anticitera e il commercio di opere d'arte in età tardo-repubblicana”, AIIN, 62, 9-30

Puglisi 2009: Puglisi M., La Sicilia da Dionisio I a Sesto Pompeo. Circolazione e funzione della moneta, Messina.

Rocchetti 1961: Rocchetti L., "Lasios”, EAA IV, Roma, 491.

Slane 1997; Slane K.; "The fine wares" in Sharon Herbert (ed.), Tel Anafa II,i, Ann Arbor, 247-416. 


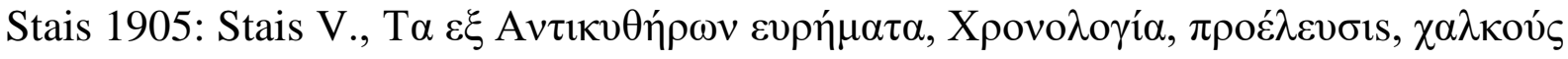
$\varepsilon \dot{\varphi}\rceil \beta$ s, Athens.

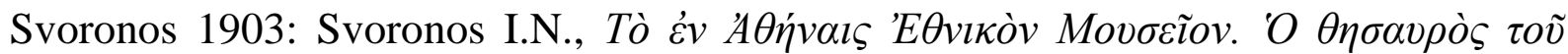

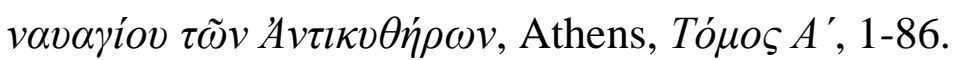

Tselekas 2012: Tselekas P., "The coins", in Kaltsas et al., 216-226.

Vivliodetis 2012: Vivliodetis E., "The lagynoi", in Kaltsas et al., 152-163.

Vlachogianni 2012: Vlachogianni E., "Sculpture", in Kaltsas et al., 62-115.

Wright 2004: Wright M.T., "The Scholar, the Mechanic and the Antikythera Mechanism.” Bulletin of the Scientific Instrument Society 80, 4-11.

\section{Illustrations}

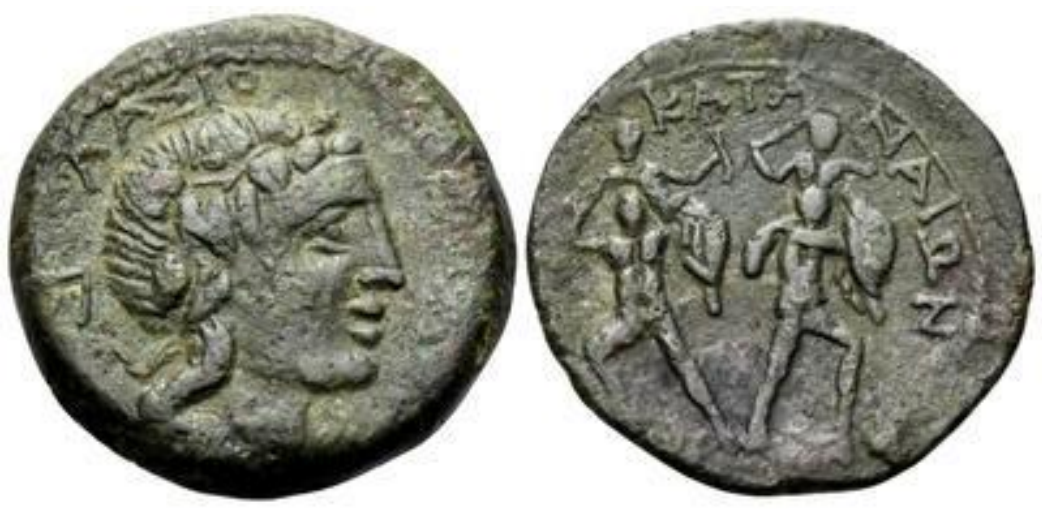

Pic. 1.

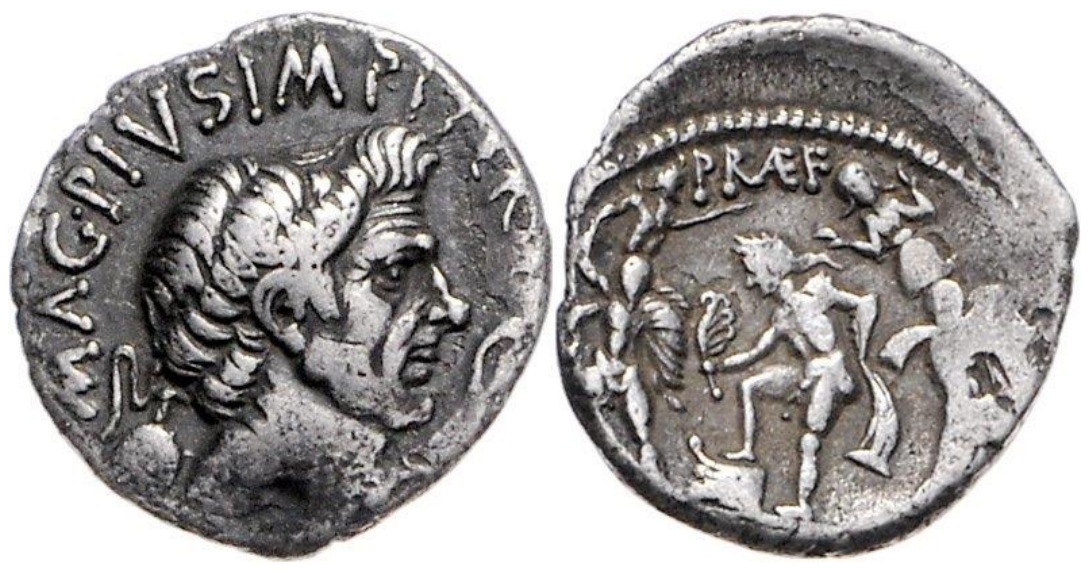

Pic. 2.

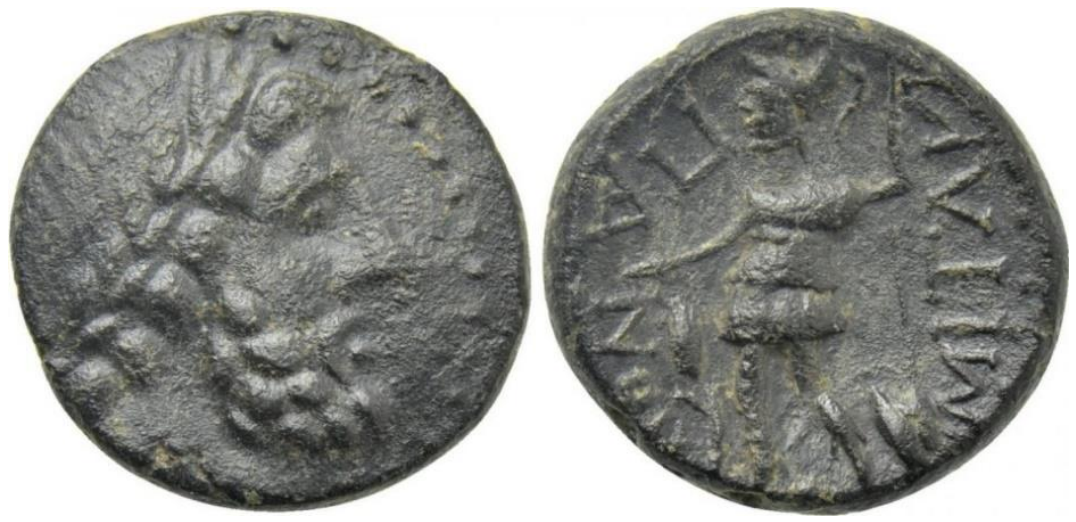

Pic. 3. 
Украӥнський нумізматичний щорічник. Вип. 5. Переяслав, 2021.

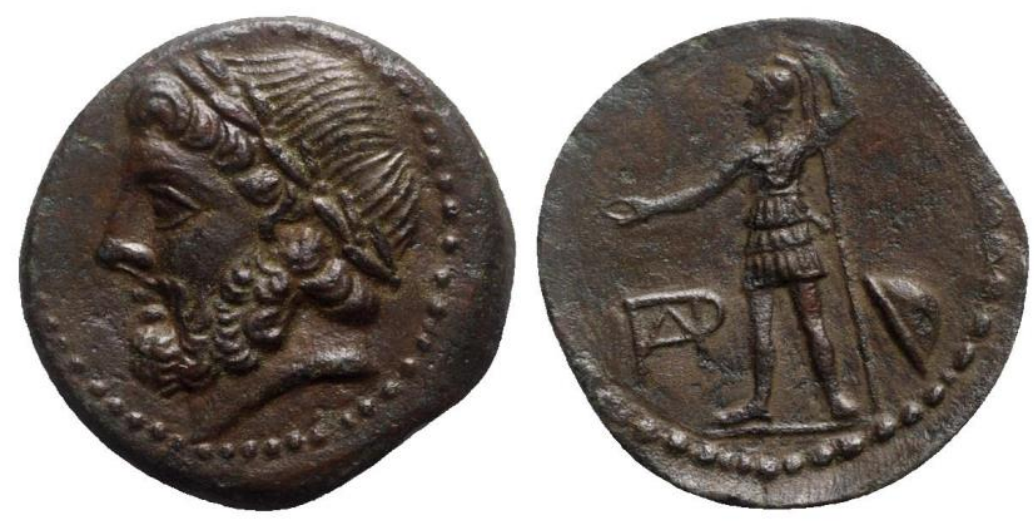

Pic. 4.

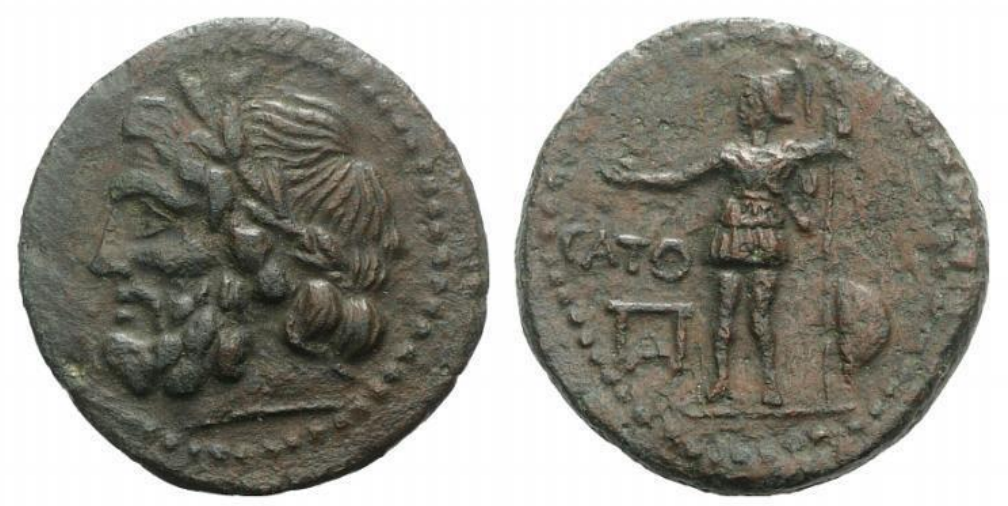

Pic. 5. 